\title{
The quest for the ganglioside functions; what did we learn more from «evo-devo» or signaling of long-term maintenance?
}

\author{
M. Heffer-Lauc, A. Mojsovic-Cuic ${ }^{1}$, P. Hrabac 2 , B. Viljetic, D. Dikic ${ }^{3}$
}

School of Medicine, Josip Juraj Strossmayer University of Osijek

4, Huttlerova, Osijek, Croatia, 31000

${ }^{1}$ University of Applied Health Studies, University of Zagreb

38, Mlinarska, Zagreb, Croatia, 10000

${ }^{2}$ Croatian Institute for Neuroscience, University of Zagreb

11 , Salata, Zagreb, Croatia, 10000

${ }^{3}$ Faculty of Science, University of Zagreb

6, Rooseveltov trg, Zagreb, Croatia, 10000

mheffer@mefos.hr

\begin{abstract}
Gangliosides are characteristic extracellular-facing plasma membrane determinants in vertebrate brain. The four major gangliosides (GM1, GDIa, GDIb and GT1b) dominate among more than one hundred glycolipid structures in nervous tissue. During brain development the expression of simple gangliosides shifts toward more complex ones, accompanied by a multiple increase in their total amount. The shift is precisely regulated and some specific structures represent well established neurodevelopmental milestones. From the evolutionary perspective, the ganglioside content in fish and amphibian brain is significantly lower than in mammalian brain, but the general variability is greater. More-polar structures, abundant in Antarctic fishes, are rare in higher vertebrates or expressed only in a narrow developmental frame. Reptiles, birds and mammals share identical common structures expressed in similar patterns with minor interspecies differences. On the contrary, fish and amphibian brains show significant interspecies differences in amount, structure and expression patterns. The initial assumption of evolutionary studies was that the variations in lipid content, particularly the glycolipid content, during temperature adaptations in ectothermic and hibernating heterothermic animals, represent an efficient molecular mechanism of the membrane function preservation. Studies of ordered lipid domains in the last decade verified the ganglioside-mediated regulation of membrane proteins (receptor kinases, neurotransmitter receptors and ion channels) as well as receptor-ligand interaction important for cell signaling.
\end{abstract}

Keywords: gangliosides, brain, evolution, development, cell-signaling, lipid rafts.

Introduction Lipids constitute $50 \%$ of brain dry weight [1]. Gangliosides contribute in the total lipid content with 10-12\% [2]. They are present in some intracellular structures, but prevail in external leaflet of

(C) Institute of Molecular Biology and Genetics NAS of Ukraine, 2010 plasma membrane, which gives them a role of the major cell surface determinants on vertebrate nerve cells [3]. Amphiphatic in nature, they consist of lipophilic ceramide moiety and hydrophilic sugar chain. Differently from other glycosphingolipids, the ganglioside sugar chain carries one or more sialic acid residues. At 
the moment 188 ganglioside structures in vertebrate tissues have been described merely based on a variety of sugar chains, but heterogeneity is considerably wider when the variety in lipophilic components is taken into consideration [4].

Such a variety would be very difficult to handle if brains of mammals and birds did not express the same four major structures (GM1, GD1a, GD1b and GT1b) which make up high $97 \%$ of gangliosides in, for example, human brain [5].

Gangliosides biosynthesis starts in the endoplasmatic reticulum and finishes by stepwise addition of single carbohydrate residues by glycosylation machinery in the Golgi complex [6]. Glycosyltransferases act in succession along Golgi-compartments (Fig. 1). Some of them compete for common specific acceptors and/or generate more than one product. The cellular pattern of gangliosides is dependent on available activated sugars, expression and the balance between the activities of the competing glycosyltransferases [7]. Changes in the steady state concentration of cellular gangliosides can be predicted by the multienzyme kinetic analysis $[8,9]$.

Gangliosides bind side by side to different receptors $[10,11]$ as a part of lipid shell [12], performing «chaperone-like» effect, probably already in Golgi apparatus. Once transported to the cell surface gangliosides become a privileged partner of cholesterol in lipid rafts modulating activities of plasma membrane proteins or participating in intercellular interactions [13].

Gangliosides in vertebrate evolution. Since glycosphingolipids are present in ten times higher concentrations in the brain than in any other extraneural tissue, it was assumed that nervous tissues require some particular functions served by each known ganglioside. It was likewise assumed that the functions were introduced with some order during the evolution. The first surveys of interspecies differences described a great variation in quantity and pattern of gangliosides in vertebrates [14, 15], particularly between different species of fish [16]. The most pronounced differences were in the quantity of lipid bound sialic acid per gram of fresh tissue between lower and higher vertebrates. While in fish brain quantities were between 110 and $750 \mu \mathrm{g} / \mathrm{g}$ of fresh tissue [17], in mammals they were between 650 and $1200 \mu \mathrm{g} / \mathrm{g}$ [18]. If species of fish were correlated according to preferred ambient temperature, then species living in warm tropical waters, like Tilapia and Pseudotrophaeus, had three times higher concentrations of lipid bound sialic acid $[17,19]$ apart from the ones living in cold waters like carp and trout [20].

The pattern of brain gangliosides is also significantly different between warm and cold-blooded animals and can be correlated to the state of thermal adaptation [21] - the lower environmental or body temperature is, the more polar is the composition of brain gangliosides. The drastic change in brain gangliosides pattern between warm and cold-blooded animals was accompanied with a difference in activities of sialotransferases in ganglioside biosynthesis [22]. On the other hand the pattern of brain gangliosides in related species of teleostea, anurans, urodela or mammals, was similar $[19,23,24]$. Variations were greater between different genera than between species of the same genus. The highest quantity (34-39\%) of the most polar tetra, penta and hexasialogangliosides in a vertebrate brain have been found in Antartic pearch and other Notothenoidea living below freezing point $\left(-1.5^{\circ} \mathrm{C}\right)$ [25], while in mammals it was between 1 and $9 \%$ [26]. Another important difference between warm and cold acclimated species was quantity of alkali-labile gangliosides. Mammalian brains had minor quantity of alkali-label gangliosides (about $5 \%$ ), warm-stenothermic cichlid fish acclimated to an ambient temperature of $28{ }^{\circ} \mathrm{C}$ have $34 \%$, European temperate species like carp have 53-59\%, while red-blooded Antarctic fish living below $0{ }^{\circ} \mathrm{C}$ could have $61-67 \%$ [27].

Most of this biochemical data have never been further investigated with immunohistochemical methods. One recent immunohistochemical study showed an interspecies difference in the expression of GD1a in olfactory bulb and olfactory pathways of frog [28] (data in press). While Ranidae sp. from all complex gangliosides had only GD1a expressed in the main and accessory olfactory tract throughout telencephalic structures transmitting olfactory clue toward amygdala (Fig. 2), the expression of the same molecule in Bufidae sp. was limited to the mitral and granule cell layer of the main olfactory tract (Fig. 3). Myelin associated glycoprotein (MAG), a possible ligand for GD1a, was expressed in a different subset of fibers, which suggested the unrelated function of these molecules in the frog brain. Previous biochemical studies of Rana sp. also 


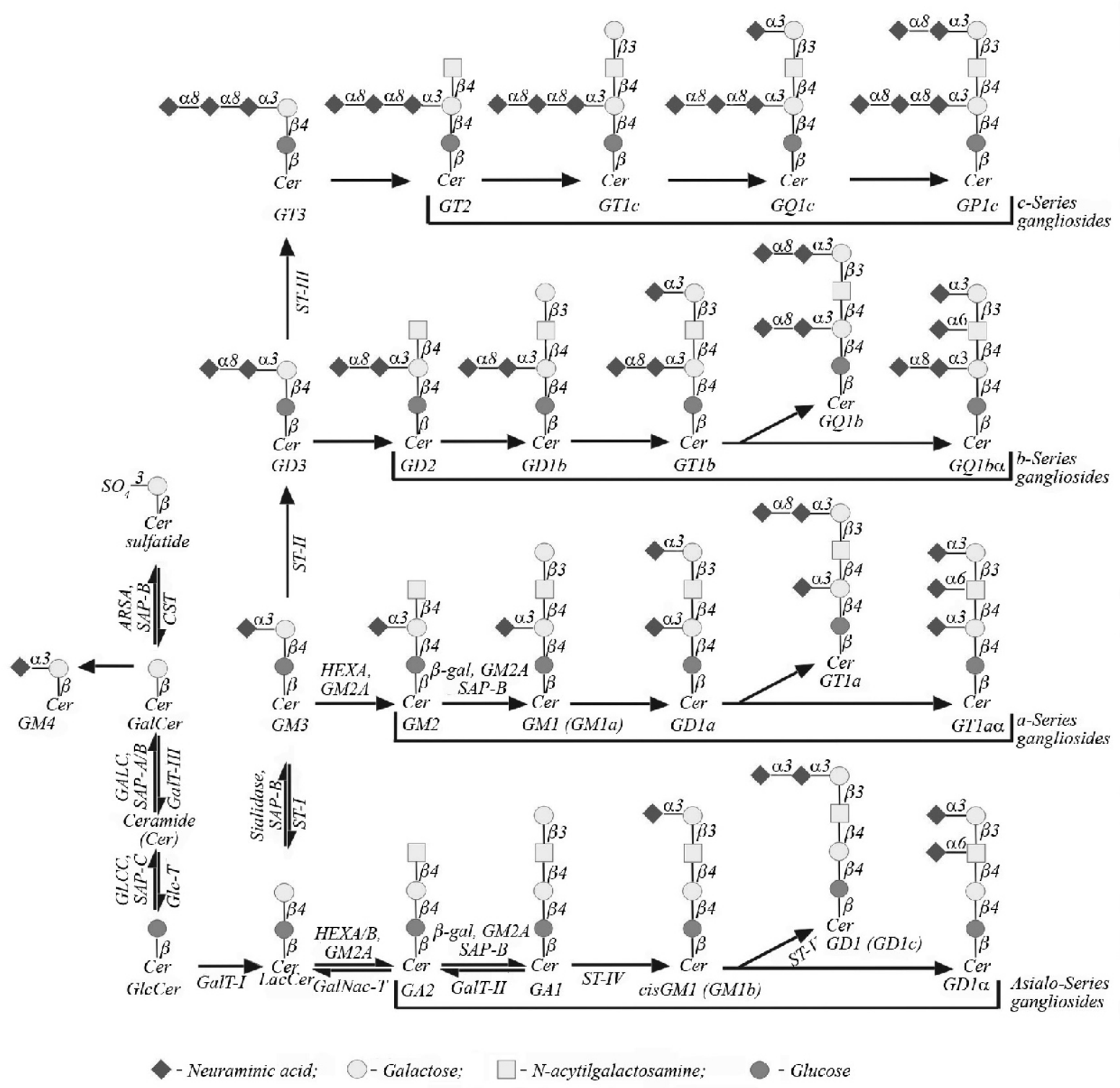

Fig. 1. Metabolic pathways and structures of glycosphingolipids. The names of enzymes participating in biosynthesis are written below arrows, while the names of enzymes and proteins participating in ganglioside degradation are written above arrows. List of abbreviations: $A R$ $S A$ - arylsulfatase; $\beta$-gal-lysosomal acid $\beta$-galactosidase; $C e r$ - ceramide; $C S T$ - cerebroside sulfotransferase (sulfatide synthase); GALCgalactosylceramidase; GalNAc-T - N-acetylgalactosaminyltransferase I (GA2/GM2/GD2/GT2-synthase); GalT-I - galactosyltransferase I (lactosylceramide synthase); GalT-II - galactosyltransferase II (GA1/GM1/GD1b/GT1c-synthase); GalT-III - galactosyltransferase III (galactosylceramide synthase); GLCC-glucosylceramidase; GlcT-glycosiltransferase (glucosylceramide synthase); GM2A - GM2 activator protein; $H E X-\beta-\mathrm{N}$-acetylhexosaminidase; $S A$ - sialic acid; $S A P$ - saposin; $S T$ - $I$ - sialyltransferase I (GM3-synthase); $S T$ - $I I-$ sialyltransferase II (GD3-synthase); $S T$-III - sialyltransferase III (GT3-synthase); $S T$ - $I V$ - sialyltransferase IV (GM1b/GD1a/GT1b/GQ1c-synthase); $S T$-V - sialyltransferase V (GD1c/GT1a/GQ1b/GP1c-synthase); $S T$-VII - sialyltransferase VII (GD1 $\alpha / G T 1$ a $\alpha / G Q 1 b \alpha / G P 1$ c $\alpha$-synthase)

found GD1a [29], but migrating differently on TLCplates than GD1a from mammalian brain, possibly because of a different ceramide anchor. The same biochemical study found also GT1b, which was not supported with immunochemistry. Another charac- teristic of the GD1 a expression in Ranidae is staining of fiber tracts, which is uncommon in mammals (compare Fig. 2 and 4).

The problem of all future comparative immunohistochemical interspecies studies would be similar: a 


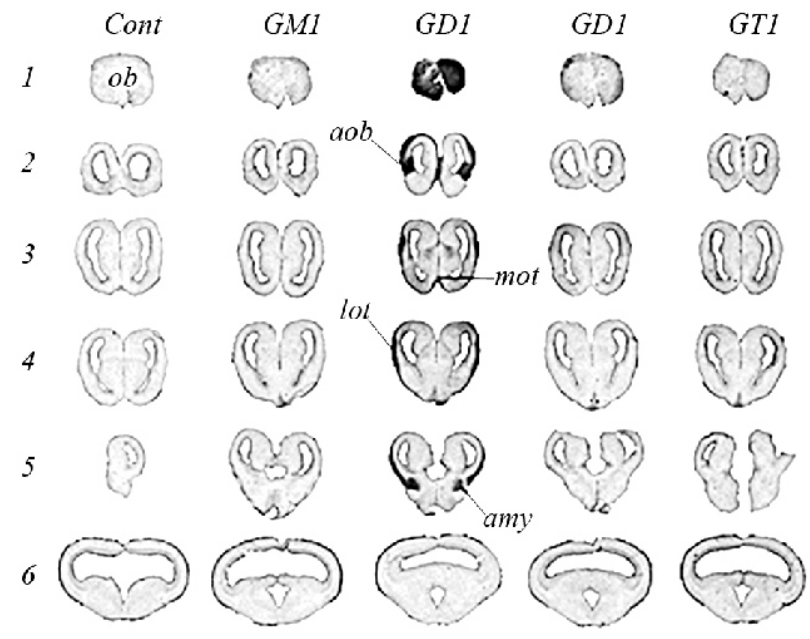

Fig. 2. Distribution of gangliosides GM1, GD1a, GD1b and GT1b in coronal sections of Rana esculenta brain (published results, with permission of authors). Expression of gangliosides was studied qualitatively using highly specific monoclonal antibodies to gangliosides GM1, GD1a, GD1b and GT1b (Seikagaku, Tokyo, Japan). The negative control was performed by omitting primary antibody (control). There were no staining with anti-GM1, anti-GD1b and anti- GT1b. The strong expression of ganglioside GD1a was in the main and accessory olfactory bulb. The major projections from mitral cell layer of the main olfactory bulb i. e. medial and lateral olfactory tract strongly expressed GD1a and could be followed through medial and lateral cortices to medial septal nuclei and amygdale. List of abbreviations: $O b$ - olfactory bulb; $a o b-$ accessory olfactory bulb; mot - medial olfactory tract; lot - lateral olfactory tract; amy - amygdala lack of antibodies toward rare ganglioside structures synthesized in different species, a difference in antibody binding to the ganglioside epitop with a different ceramide anchor [30], alkali-labile modifications in some species [31], accessibility of epitop due to diffe rent density in the membrane and just a few well described model organisms for a big taxa like Teleostea.

The role of gangliosides in the evolutionary perspective, after the discovery of lipid rafts [32], became more interesting than ever. Lipid rafts have been described as transient membrane domains enabling gathering together molecules that are taking part in receiving, transmitting and amplifying incoming signals [33], while sphingolipids are master regulators of their dynamics [34]. It is very likely that the most common complex ganglioside structures serve the same functions in the rafts of all homothermic mammals [18], because they share the same pattern of distribution (Fig. 4 , unpublished results of our laboratory). The interesting open questions come from hibernating mammals, like dormice and hamster, who change the ration of GD1a and GT1b in favor of GT1b during winter season [35], while the change was limited just to basal brain and cortex, circumventing cerebellum. The maintenance of membrane properties in Teleostea is achieved by different mechanisms, considerably varying between genera. During cold-acclimation from $20^{\circ} \mathrm{C}$ to $4{ }^{\circ} \mathrm{C}$ in
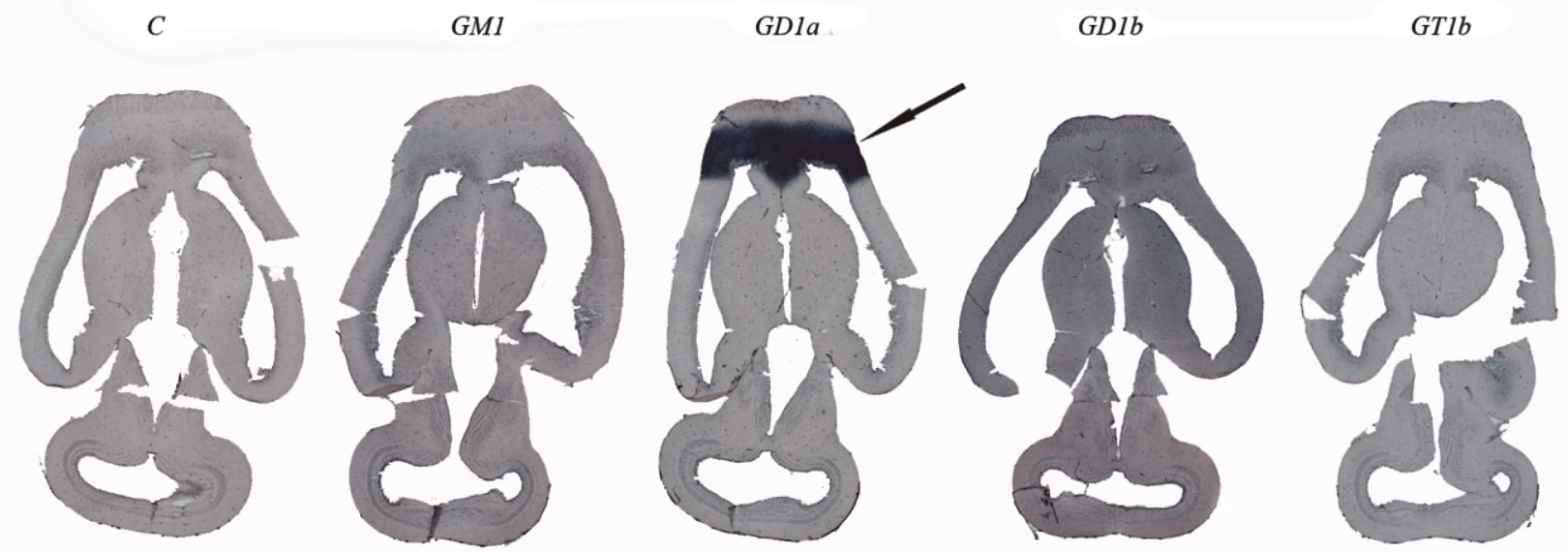

Fig. 3. Distribution of gangliosides GM1, GD1a, GD1b and GT1b in horizontal sections of Bufo bufo. (partially published results from our group). Expression of gangliosides was studied qualitatively using highly specific monoclonal antibodies to gangliosides GM1, GD1a, GD1b and GT1b (Seikagaku, Tokyo, Japan). The negative control was performed by omitting primary antibody (control).

There were no staining with anti-GM1, anti-GD1b and anti-GT1b. The strong expression of ganglioside GD1a was just in the main olfactory tract. Black arrow points to the main olfactory tract. 


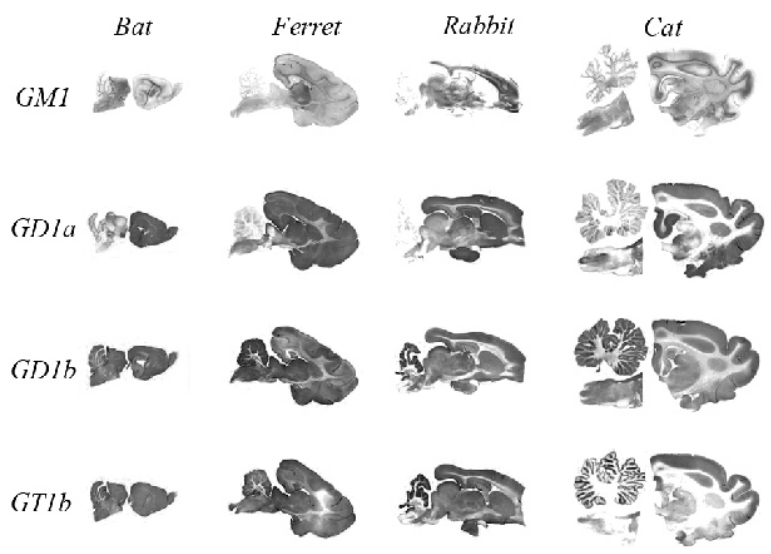

Fig. 4. Distribution of gangliosides GM1, GD1a, GD1b and GT1b in sagittal sections of selected mammalian brains: bat, ferret, rabbit and cat (unpublished results from our group). Expression of gangliosides was studied qualitatively using highly specific monoclonal antibodies to gangliosides GM1, GD1a, GD1b and GT1b (Seikagaku, Tokyo, Japan). In all studied animals anti-GM1 stains fiber tracts. In ferret and cat brain GM1 is also in all or just deep layers of cortex. All studied mammals express GD1b in layers of cortex and fiber tracts, while GD1a and GT1b give mostly neuronal staining

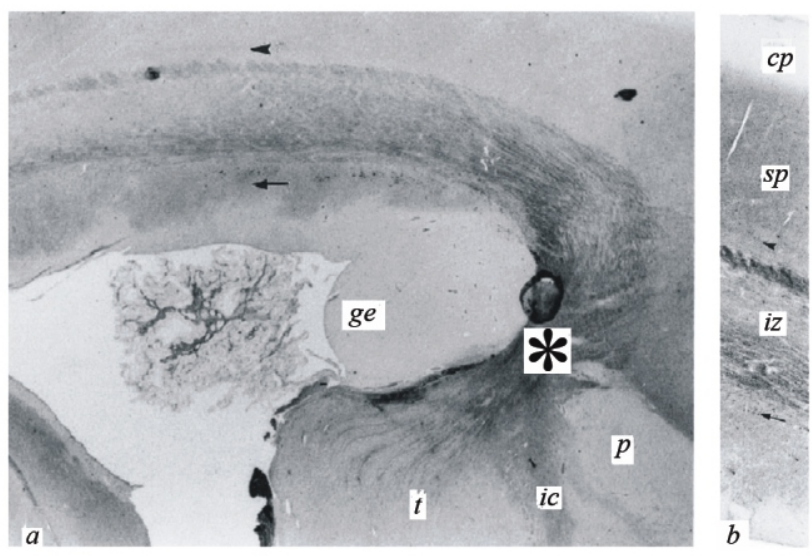

Fig. 5. Distribution of c-series gangliosides stained with Q211 antibody in horizontal sections of 23-week-old human fetal cerebrum (published results, reproduced with permission of authors): $A-$ immunoreactivity was within thalamocortical fibers (asterix) extending from the thalamus through the internal capsule into the intermediate zone; $B$ - enlargement of cortical wall. Immunoreactivity was localized to intermediate and subplate zones, just below negative cortical plate. The arrowhead marks the border between the intermediate and subplate zone and arrow marks the border between the intermediate and subventricular zone. List of abbreviations: $c p-$ cortical plate; $g e$ - ganglionic eminence; $i c$ - internal capsule; $i z-$ intermediate zone; $p$ - putamen; $t$ - thalamus; $s p$ - subplate zone

the carp brain the concentration of phosphatidylethanolamin in cost of phosphatidylcholine increased and the ratio of cholesterol to phospholipids decreased in just two weeks [21], but changes in the quantity of poly- sialogangliosides took six weeks [19]. In trout brain cold-acclimation produced a very different shift in ganglioside biosynthesis - decrease of monosialogangliosides, slight increase in di- and trisialogangliosides and no changes in polysialogangliosides [36]. Lipid rafts in thermal acclimation of trout pass through a compositional change not just varying in sphingolipids but also cholesterol, receptors and signaling molecules [37, 38]. When these changes happen in the brain changes in behavior or alterations in complex processes like regeneration might occur. Recent cloning of enzymes involved in ganglioside biosynthesis in fish and amphibian brain could be the first step into this interesting field [39-41].

The role of gangliosides in brain development. The first studies of gangliosides expression in developing mammalian brain were based on lipid extraction, method of variable sensitivity, producing conflicting results [42-45]. The few basic concepts emerged from all studies: brain development starts with low concentrations of simple gangliosides GM3 and GD3, complex gangliosides appear with the first cortical neurons, their concentration multiplies a few times during axonogenesis and synaptogenesis, reaches the plateau with myelination and then is maintained through adulthood [46]. Early studies also showed that while the quantity of simple gangliosides like GM3 and GD3 decreases rapidly during development, the quantity of complex gangliosides increases with complex gangliosides of «c-pathway» and shifts toward «b» and finally «apathway» [46].

The observed shift in the synthesis is not connected with the exchange in the expression of two key glycosyltransferases (Fig. 1), ST-II (GD3-synhase) and $\mathrm{N}$-acetylgalactosaminyltransferase (GalNAcT, GM2/ GD2 synthase), but with a posttranslational processing and complex formation between existing trasferases [9].

In that time biochemical studies were poor in distinguishing the classes of neurons or even layers of the cortex, but studies of adult brain at least established the idea of a regional pattern identity $[47,48]$. There were a few attempts to understand laminar distribution of gangliosides like inventive study of a particularly enlarged «subplate layer» in the human fetal neopallium at 28 weeks of gestation [49] and developmental studi- 
es of mutant mice missing particular neuronal subpopulation $[50,51]$. More precise determination of regional and cellular distribution had to wait for the production of anti-ganglioside antibodies, which turned out to be a very challenging task because ubiquitously presented gangliosides were not highly immunogenic.

Beside dramatic changes in the synthesis of complex gangliosides development is accompanied with the appearance of some minor structures like «c-series» polysialogangliosides [52, 53], lactotetraose series [54] and 9-O-acetylated gangliosides [55]. These minor structures are much more immunogenic and the first high affinity antibody was raised against «c-series» polysialogangliosides [56]. Immunohistochemical studies [56] and particularly the use of this antibody in cell cultures [57] suggested the role of polysialogangliosides in axon fasciculation, migration and aggregation. The same series is present in the human brain (Fig. 5) in a transient fetal structure [58] characteristically enlarged in humans [59].

In the next few years antibodies against all major [60] and some of minor gangliosides [61, 62] of the brain were raised. Finally, it was possible to see distribution of each ganglioside in adult [62-64] and developing brain [65]. However, the results were providing vague clues about a distinct function. The misunderstanding was partially caused by the specificity of individual antibodies [66-68], other in the difference of fixation methods [69] and one, much unexpected, came from the use of detergents [70-72]. It seemed that the problem of specificity was finally solved with the production of highly specific mouse IgG antibodies for complex gangliosides raised in Galgt 1 knockout mouse [73], deficient in synthesis of complex gangliosides. Antibodies were highly specific, but still inefficient in some cases. In the case of ganglioside antibodies target recognition is defined by fine specificity of antibody and ganglioside orientation/exposure in the tissue [74]. Recently it is possible to overcome the limitations of immunohystochemistry using imaging mass spectrometry technology [75].

As the quantity and the pattern of gangliosides in brain by itself does not imply the function, researchers turn to a more flexible model - neuronal cell cultures. In 1995 a group of researchers [76] noted that the inhibition of sphingolipid synthesis with the inhibitor of glucosyceramide synthetase D-threo-1-phenyl-2-decanoylamino-3-morpholino-1-propanol (PDMP) would affect the length of axons and branching. Their later work showed that major changes in ganglioside synthesis occurred during axonogenesis and axon elongation, but not during dendrite growth or synaptogenesis [77]. At the same time the first glycosphingolipid receptors of axonal membrane, GD1a and GT1b, were discovered interacting with MAG on oligodendrocyte [78]. Differently from gangliosides, MAG appears at the final stages of development and its biding to gangliosides promotes axon-myelin stability and inhibits axon outgrowth after injury [79]. Such a developmentally late interaction has no impact on brain development and even has very mild neurological progress, which caused confusion when the first B4galnt1 or GM2/GD2 synthase knockout mice appeared with a block in the synthesis of complex gangliosides [80]. To make it even more complicated, the total brain ganglioside concentration in these mice is the same as in the wild-type mice and one of simple gangliosides (GM3) interacts with MAG, further protracting onset of Wallerian degeneration [81, 82].

The story of $B 4$ galnt 1 mice made researchers more alert to the unexpected knockout mouse phenotype. Just one of all generated knockout mice for ganglioside biosynthesis, UDP-glucose ceramide glucosyltransferase, was embryonic lethal [83]. It was not surprising because it is the enzyme leading to the synthesis of all major complex gangliosides, but deserved closer look to understand if lethality was caused by neurological reasons. It turned out that conditional knockouts for the same gene in neuronal and glial cells were not embryonicaly lethal, but either displayed abnormal behavior by 2-3 months of age [84] or died after the onset of myelination [85], both with abnormalities and a loss of Purkinje cells. Knockouts defective for «b-series» gangliosides (GD3 synthase) are without phenotype, while double knockout of this mice and B4galnt1 have high mortality rate due to audiogenic seizures [86].

The major role of gangliosides in the nervous system is maintenance of the neuronal function in the adulthood. Such a role does not seem to be of high importance, but in fact maintenance makes all complex systems sustainable. Imagine a house without maintenance, how long would it last. Imagine how much ener- 
gy would be lost if you had to rebuild the house on regular basis just because you are not able to perform maintenance. In case of perfectly operational maintenance, you are able to give up some expensive, complicated or very slow functions, like for example regeneration. Gangliosides are just one of cellular mechanisms serving at cell membranes in maintenance of lipid rafts [87], lubricating signaling pathways [88] and chaperoning a number of cell proteins [11].

\section{М. Хеффер-Лаук, А. Можсович-Чуік, Б. Вільжетич, Д. Дикич}

Пошук функцій гангліозидів; що нового ми дізналися 3 «evo-devo», або сигналінг довготривалого збереження

Резюме

Гангліозиди - характеристичні детермінанти, які локалізовані на зовнішній поверхні мембран клітин мозку хребетних. Чотири основних гангліозиди (GM1, GDIa, GD1b i GT1b) переважають серед сотень інших сполук гліколіпідів нервової тканини. У процесі розвитку мозку експресія простих гангліозидів змішується у бік синтезу більш складних сполук, щзо супроводжується багаторазовим зростанням їхньої загальної кількості. Зміщення експресії - строго регульований процес, за якого поява деяких специфічних структур репрезентує добре відомі стадї розвитку нервової тканини. 3 точки зору еволюиії вміст гангліозидів у мозку риб та амфібій значно нижчий, ніж у мозку ссавиів, проте загальна їхня варіабельність суттево вища. Більш полярні сполуки, які широко представлені у антарктичних риб, є рідкісними для ссавців або характерними для певного короткотривалого етапу онтогенезу. Плазуни, птахи і ссавиі зберігають ідентичні спільні структури, що мають подібні патерни експресії з незначними міжвидовими відмінностями. Навпаки, для мозку риб та амфібій відзначено істотну міжвидову відмінність щңодо кількості, структури та патерну експресї. Першочерговим припущенням еволюиіииного дослідження стало те, щзо варіації у вмісті ліпідів, зокрема гліколіпідів, під час температурної адаптації у холоднокровних і гетеротермних тварин, які впадають у сплячку, є високоефективним молекулярним механізмом захисту функиіонування мембран. Вивчення впорядкованих доменів ліпідів за останне десятиліття підтверджує гангліозид-опосередковану регуляцію мембранних білків (рецептори з кіназною активністю, рецептори нейротрансмітерів та іонні канали), так само як і взаємодію рецептор-ліганд, важливу для передачі позаклітинного сигналу.

Ключові слова: гангліозиди, головний мозок, еволючія, розвиток, клітинна сигналізація, lipid rafts.

М. Хеффер-Лаук, А. Можсович-Чуик, Б. Вильжетич, Д. Дикич

Поиск функций ганглиозидов; что нового ми узнали из «evo-devo», или сигналинг длительного сохранения

Резюме

Ганглиозиды - характеристические детерминанты, локализованные на внешней поверхности мембран клеток мозга хребетных. Четыре основных ганглиозида (GM1, GDIa, GDIb u GT1b) преобладают среди сотень других соединений гликолипидов нервной ткани. В процессе развития мозга экспрессия простых ганглиозидов замещается синтезом более сложных соединений, что сопровождается многократным увеличением их общего количества. Смещение экспрессии - строго регулированный проиесс, при котором появление некоторых специфических структур представляет хорошо известные стадии развития нервной ткани. Содержание ганглиозидов в мозге рыб и амфибий значительно ниже, чем в мозге млекопитающих, однако их общая вариабельность существенно выше. Более полярные соединения, широко представленные у антарктических рыб, являются редкими для млекопитающих или характерными для определенного кратковременного этапа онтогенеза. Пресмыкающиеся, птицы и млекопитающие сохраняют общие идентичные структуры с подобными паттернами экспрессии, имеющими незначительные межвидовые отличия. Наоборот, для мозга рыб и амфибий отмечены существенные межвидовые отличия, касающиеся количества, структуры и паттерна экспрессии. Первоочередным предположением эволючионного исследования стало то, что вариации в содержании липидов, в частности гликолипидов, во время температурной адаптации у хладнокровных и гетеротермных животных, впадающих в спячку, являются высокоэффективным молекулярным механизмом защиты функиионирования мембран. Изучение упорядоченных доменов липидов за последнее десятилетие подтверждает ганглиозид-опосредованную регуляцию мембранных белков (рецепторы с киназной активностью, рецепторы нейротрансмиттеров и ионные каналы), так же как и взаимодействие реиептор-лиганд, важное для передачи внеклеточного сигнала.

Ключевые слова: ганглиозиды, головной мозг, эволюция, развитие, клеточная сигнализациф, lipid rafts.

\section{REFERENCES}

1. Woods A. S., Jackson S. N. Brain tissue lipidomics: direct probing using matrix-assisted laser desorption/ionization mass spectrometry // AAPS. J.-2006.-8, N 2.-P. E391-395.

2. Tettamanti $G$. Ganglioside/glycosphingolipid turnover: new concepts // Glycoconj. J.-2004.-20, N 5.-P. 301-317.

3. Schnaar R. Neural function of glycolipids // Comprehensive glycoscience / Ed. J. P. Kamerling.-Amsterdam: Elsevier, 2007.-P. 323-337.

4. Yu R. K., Ariga T. Glycosphingolipid structures // Comprehensive glycoscience / Ed. J. P. Kamerling.-Amsterdam: Elsevier, 2007.-P. 73-122.

5. Tettamanti G., Bonali F., Marchesini S.Zambotti V. A new procedure for the extraction, purification and fractionation of brain gangliosides // Biochim. Biophys. Acta.-1973.-296, N 1.-P. 160-170.

6. Maccioni H. J. Glycosylation of glycolipids in the Golgi complex // J. Neurochem.-2007.-103, Suppl 1.-P. 81-90.

7. Maxzud M. K., Daniotti J. L., Maccioni H. J. Functional coupling of glycosyl transfer steps for synthesis of gangliosides in Golgi membranes from neural retina cells // J. Biol. Chem.-1995.-270, N 34.-P. 20207-20214.

8. Bieberich E., MacKinnon S., Silva J., Li D. D., Tencomnao T., Irwin L., Kapitonov D., Yu R. K. Regulation of ganglioside biosynthesis by enzyme complex formation of glycosyltransferases // Biochemistry.-2002.-41, N 38.-P. 1147911487. 
9. Yu R. K., Bieberich E., Xia T., Zeng G. Regulation of ganglioside biosynthesis in the nervous system // J. Lipid. Res.2004.-45, N 5.-P. 783-793.

10. Kabayama K., Sato T., Saito K., Loberto N., Prinetti A., Sonnino S., Kinjo M., Igarashi Y., Inokuchi J. Dissociation of the insulin receptor and caveolin-1 complex by ganglioside GM3 in the state of insulin resistance // Proc. Nat. Acad. Sci. USA.-2007.-104, N 34.-P. 13678-13683.

11. Fantini J., Barrantes F. J. Sphingolipid/cholesterol regulation of neurotransmitter receptor conformation and function // Biochim. Biophys. Acta.-2009.-1788, N 11.-P. 2345-2361.

12. Anderson R. G., Jacobson K. A role for lipid shells in targeting proteins to caveolae, rafts, and other lipid domains // Science.-2002.-296, N 5574.-P. 1821-1825.

13. Lopez P. H., Schnaar R. L. Gangliosides in cell recognition and membrane protein regulation // Curr. Opin. Struct. Biol.2009.-9, N 5.-P. 549-557.

14. Yiamouyiannis J. A., Dain J. A. The appearance of ganglioside during embryological development of the frog // J. Neurochem.-1968.-15, N 7.- P. 673-676.

15. Hunter G. D., Wiegant V. M., Dunn A. J. Interspecies comparison of brain ganglioside patterns studied by two-dimensional thin-layer chromatography // J. Neurochem.-1981.37, N 4.-P. 1025-1031.

16. Ishizuka I., Kloppenburg M., Wiegandt H. Characterization of gangliosides from fish brain // Biochim. Biophys. Acta.1970.-210, N 2.-P. 299-305.

17. Rahmann H., Hilbig R., Probst W., Muhleisen M. Involvement of temperature in the composition of fish brain gangliosides // J. Therm. Biol.-1983.-8, N 1-2.-P. 107-109.

18. Kappel T., Hilbig R., Rahmann H. Variability in brain ganglioside content and composition of endothermic mammals, heterothermic hibernators and ectothermic fishes // Neurochem. Int.-1993.-22, N 6.-P. 555-566.

19. Hilbig R., Rahmann $H$. Variability in brain gangliosides of fishes // J. Neurochem.-1980.-34, N 1.-P. 236-240.

20. Avrova N. F. Gangliosides in fish brain // Adv. Exp. Med. Biol.-1980.-125. -P. 177-183.

21. Rahmann H., Jonas U., Kappel T., Hilderbrandt H. Differential involvement of gangliosides versus phospholipids in the process of temperature adaptation in vertebrates. A comparative phenomenological and physicochemical study // Ann. N. Y. Acad. Sci.-1998.-845.-P. 72-91.

22. Freischutz B., Saito M., Rahmann H., Yu R. K. Activities of five different sialyltransferases in fish and rat brains // J. Neurochem.-1994.-62, N 5.-P. 1965-1973.

23. Irwin L. N., Schwartz K. Amphibian brain gangliosides: pattern analysis by two-dimensional thin-layer chromatography // Comp. Biochem. Physiol. B.-1983.-76, N 3.-P. 649-651.

24. Irwin L. N., Irwin C. C. Phylogenetic and regional variations in brain gangliosides of tetrapods // Comp. Biochem. Physiol. B. $-1979 .-64$, N 1.-P. 121-123.

25. Becker K., Wohrmann A. P. A., Rahmann. Brain gangliosides and cold-adaptation in high-Antartic fish // Biochem. System. Ecol.-1995.- 23, N 7-8.-P. 695-707.

26. Ledeen R. W., Yu R. K. Gangliosides of the nervous system // Ganglioside function / Eds G. C. B. Porcellati, B. Ceccarelli, G. Tettamanti.-New York; London: Plenum press, 1976.P. 191-204.

27. Becker K., Rahmann H. Influence of ambient temperature on content and composition of brain gangliosides in vertebrates // Comp. Biochem. Physiol. B. Biochem. Mol. Biol.-1995.111, N 2.-P. 299-310.
28. Viljetic B., Degmecic I. V., Krajina V., Bogdanovic T., Mojsovic A., Dikic D., Vajn K., Schnaar R. L., Heffer-Lauc M. Distribution of major brain gangliosides in olfactory tract of frogs // Coll. Antropol.-2010.

29. Avrova N. F. Brain ganglioside patterns of vertebrates // J. Neurochem.-1971.-18, N 4.-P. 667-674.

30. Tagawa Y., Laroy W., Nimrichter L., Fromholt S. E., Moser A. B., Moser H. W., Schnaar R. L. Anti-ganglioside antibodies bind with enhanced affinity to gangliosides containing very long chain fatty acids // Neurochem. Res.-2002.-27, N 7-8.- P. 847-855.

31. Avrova N. F., Ghidoni R., Karpova O. B., Nalivayeva N. N., Malesci A., Tettamanti $G$. Systematic position of fish species and ganglioside composition and content // Comp. Biochem. Physiol. B.-1986.-83, N 3.-P. 669-676.

32. Simons K., van Meer G. Lipid sorting in epithelial cells // Biochemistry.-1988.-27, N 17.-P. 6197-6202.

33. Rajendran L., Simons $K$. Lipid rafts and membrane dynamics // J. Cell. Sci.-2005.-118, N 6.-P. 1099-1102.

34. Mitsuda T., Furukawa K., Fukumoto S., Miyazaki H., Urano T., Furukawa K. Overexpression of ganglioside GM1 results in the dispersion of platelet-derived growth factor receptor from glycolipid-enriched microdomains and in the suppression of cell growth signals // J. Biol. Chem.-2002.-277, N 13.-P. 11239-11246.

35. Rahmann H., Hilbig R., Marx J., Beitinger H., Mehlfeld R. Brain gangliosides and hibernation // J. Therm. Biol.-1987.12, N 2.-P. 81-85.

36. Hilbig R., Rahmann H., Rosner H. Brain gangliosides and temperature adaptation in eury- and stenothermic teleost fish (carp and raibow trout) // J. Therm. Biol.-1979.-4, N 1.P. 29-34.

37. Zehmer J. K., Hazel J. R. Plasma membrane rafts of rainbow tro ut are subject to thermal acclimation // J. Exp. Biol.2003.-206, N 10.-P. 1657-1667.

38. Zehmer J. K., Hazel J. R. Membrane order conservation in raft and non-raft regions of hepatocyte plasma membranes from thermally acclimated rainbow trout // Biochim. Biophys. Acta.-2004.-1664, N 1.-P. 108-116.

39. Luque M. E., Crespo P. M., Monaco M. E., Aybar M. J., Daniotti J. L., Sanchez S. S. Cloning and functional characterization of two key enzymes of glycosphingolipid biosynthesis in the amphibian Xenopus laevis // Develop. Dyn.-2008.237, N 1.-P. 112-123.

40. Chisada S., Yoshimura Y., Sakaguchi K., Uemura S., Go S., Ikeda K., Uchima H., Matsunaga N., Ogura K., Tai T., Okino $N$., Taguchi R., Inokuchi J., Ito M. Zebrafish and mouse alpha 2,3-sialyltransferases responsible for synthesizing GM4 ganglioside // J. Biol. Chem.-2009.-284, N 44.-P. 3053430546.

41. Chang L. Y., Mir A. M., Thisse C., Guerardel Y., Delannoy P., Thisse B., Harduin-Lepers A. Molecular cloning and characterization of the expression pattern of the zebrafish alpha2, 8sialyltransferases (ST8Sia) in the developing nervous system // Glycoconj. J.-2009.-26, N 3.-P. 263-275.

42. Vanier M. T., Holm M., Ohman R., Svennerholm L. Developmental profiles of gangliosides in human and rat brain // J. Neurochem.-1971.-18, N 4.-P. 581-592.

43. Merat A., Dickerson J. W. The effect of development on the gangliosides of rat and pig brain // J. Neurochem.-1973.-20, N 3.-P. 873-880.

44. Irwin L. N., Michael D. B., Irwin C. C. Ganglioside patterns of fetal rat and mouse brain // J. Neurochem.-1980.- 34, N 6.-P. 1527-1530. 
45. Hilbig R. R. H., Rosner H., Mertz G., Segler-Stahl K., Rahmann $H$. Developmental profiles of gangliosides in mouse and rat cerebral cortex // Rouxs Arch. Develop. Biol.-1982.191, N 4.- P. 281-284.

46. Yu R. K., Macala L. J., Taki T., Weinfield H. M., Yu F. S. Developmental changes in ganglioside composition and synthesis in embryonic rat brain // J. Neurochem.-1988.-50, N 6.P. 1825-1829.

47. Kracun I., Rosner H., Cosovic C., Stavljenic A. Topographical atlas of the gangliosides of the adult human brain // J. Neu- rochem.-1984.-43, N 4.-P. 979-989.

48. Svennerholm L., Bostrom K., Jungbjer B., Olsson L. Membrane lipids of adult human brain: lipid composition of frontal and temporal lobe in subjects of age 20 to 100 years // J. Neu- rochem.-1994.-63, N 5.-P. 1802-1811.

49. Kracun I., Rosner, H., Kostovic I., Rahmann H. Areal and laminar distribution of gangliosides in the fetal human neopallium at 28 weeks of gestation // Rouxs. Arch. Develop. Biol.1983.-192, N 2.-P. 108-112.

50. Seyfried T. N., Miyazawa N., Yu R. K. Cellular localization of gangliosides in the developing mouse cerebellum: analysis using the weaver mutant // J. Neurochem.-1983.-41, N 2.P. 491-505.

51. Seyfried T. N., Bernard D. J., Yu R. K. Cellular distribution of gangliosides in the developing mouse cerebellum: analysis using the staggerer mutant // J. Neurochem.-1984.-43, N 4.P. 1152-1162.

52. Rosner $H$. A new thin-layer chromatographic approach for separation of multisialogangliosides. Novel gangliosides fractions in the embryonic chicken brain // Anal. Biochem.1980.-109, N 2.-P. 437-442.

53. Miller-Podraza H., Mansson J. E.Svennerholm L. Isolation of complex gangliosides from human brain // Biochim. Biophys. Acta.-1992.-1124, N 1.-P. 45-51.

54. Molin K., Mansson J. E., Fredman P., Svennerholm L. Sialosyllactotetraosylceramide, 3'-isoLM1, a ganglioside of the lactotetraose series isolated from normal human infant brain // J. Neurochem.-1987.-49, N 1.-P. 216-219.

55. Mendez-Otero R., Ramon-Cueto A. Expression of 9-O-acetylated gangliosides during development of the rat olfactory system // Neuroreport.-1994.-5, N 14.-P. 1755-1759.

56. Rosner H., Greis C., Henke-Fahle S. Developmental expression in embryonic rat and chicken brain of a polysialogan glioside-antigen reacting with the monoclonal antibody Q $211 / /$ Brain Res.-1988.-470, N 2.-P. 161-171.

57. Greis $C$., Rosner $H$. Migration and aggregation of embryonic chicken neurons in vitro: possible functional implication of polysialogangliosides // Brain Res. Develop. Brain. Res.1990.-57, N 2.-P. 223-234.

58. Letinic K., Heffer-Lauc M., Rosner H., Kostovic I. C-pathway polysialogangliosides are transiently expressed in the human cerebrum during fetal development // Neuroscience.-1998.-86, N 1.-P. 1-5.

59. Molliver M. E., Kostovic I., van der Loos $H$. The development of synapses in cerebral cortex of the human fetus // Brain Res.-1973.- 50, N 2.-P. 403-407.

60. Kotani M., Ozawa H., Kawashima I., Ando S., Tai T. Generation of one set of monoclonal antibodies specific for a-pathway ganglio-series gangliosides // Biochim. Biophys. Acta.1992.-1117, N 1.-P. 97-103.

61. Ferretti P., Borroni E. Putative cholinergic-specific gangliosides in guinea pig forebrain // J. Neurochem.-1986.-46, N 6.-P. 1888-1894.
62. Kotani M., Kawashima I., Ozawa H., Ogura K., Ishizuka I., Terashima T., Tai T. Immunohistochemical localization of minor gangliosides in the rat central nervous system // Glycobiology.-1994.-4, N 6.-P. 855-865.

63. Kotani M., Kawashima I., Ozawa H., Terashima T., Tai T. Differential distribution of major gangliosides in rat central nervous system detected by specific monoclonal antibodies // Glycobiology.-1993.-3, N 2.-P. 137-146.

64. Irie F., Hashikawa T., Tai T., Seyama Y., Hirabayashi Y. Distribution of cholinergic neuron-specific gangliosides (GT1a alpha and GQ1b alpha) in the rat central nervous system // Brain Res.-1994.-665, N 1.-P. 161-166.

65. Kotani M., Terashima T., Tai T. Developmental changes of ganglioside expressions in postnatal rat cerebellar cortex // Brain Res.-1995.-700, N 1-2.-P. 40-58.

66. Schlosshauer B., Blum A. S., Mendez-Otero R., Barnstable C. J., Constantine-Paton M. Developmental regulation of ganglioside antigens recognized by the JONES antibody // J. Neurosci.-1988.-8, N 2.-P. 580-592.

67. Saito M., Kitamura H., Sugiyama K. The specificity of monoclonal antibody A2B5 to c-series gangliosides // J. Neurochem.-2001.-78, N 1.-P. 64-74.

68. Schwarz A., Futerman A. H. The localization of gangliosides in neurons of the central nervous system: the use of anti-ganglioside antibodies // Biochim. Biophys. Acta.-1996.-1286, N 3.-P. 247-267.

69. Schwarz A., Futerman A. H. Determination of the localization of gangliosides using anti-ganglioside antibodies: comparison of fixation methods // J. Histochem. Cytochem.-1997.45, N 4.-P. 611-618.

70. Kawashima I., Tai T. An immunocytochemical technique with monoclonal antibodies to glycosphingolipids in rat primary cerebellar cultures: influence of detergent permeabilization // Brain Res. Brain Res. Protoc.-1998.-2, N 4.P. 299-305.

71. Heffer-Lauc M., Viljetic B., Vajn K., Schnaar R., L.Lauc G. Effects of detergents on the redistribution of gangliosides and GPI-anchored proteins in brain tissue sections // J. Histochem. Cytochem.-2007.-55, N 8.-P. 805-812.

72. Heffer-Lauc M., Lauc G., Nimrichter L., Fromholt S. E., Schnaar R. L. Membrane redistribution of gangliosides and glycosylphosphatidylinositol-anchored proteins in brain tissue sections under conditions of lipid raft isolation // Biochim. Biophys. Acta.-2005.- 1686, N 3.-P. 200-208.

73. Schnaar R. L., Fromholt S. E., Gong Y., Vyas A. A., Laroy W., Wayman D. M., Heffer-Lauc M., Ito H., Ishida H., Kiso M., Griffin J. W., Shiekh K. A. Immunoglobulin G-class mouse monoclonal antibodies to major brain gangliosides // Anal. Biochem.-2002.-302, N 2.-P. 276-284.

74. Lopez P. H., Zhang G., Bianchet M. A., Schnaar R. L., Sheikh $K$. A. Structural requirements of anti-GD1 a antibodies determine their target specificity // Brain.-2008.-131, N 7.P. 1926-1939.

75. Sugiura Y., Shimma S., Konishi Y., Yamada M. K., Setou M. Imaging mass spectrometry technology and application on ganglioside study; visualization of age-dependent accumulation of C20-ganglioside molecular species in the mouse hippocampus // PLoS. One.-2008.-3, N 9.- P. e3232.

76. Schwarz A., Rapaport E., Hirschberg K.Futerman A. H. A regulatory role for sphingolipids in neuronal growth. Inhibition of sphingolipid synthesis and degradation have opposite effects on axonal branching // J. Biol. Chem.-1995.-270, N 18.-P. 10990-10998. 
77. Hirschberg K., Zisling R., van Echten-Deckert G., Futerman $A$. $H$. Ganglioside synthesis during the development of neuronal polarity. Major changes occur during axonogenesis and axon elongation, but not during dendrite growth or synaptogenesis // J. Biol. Chem.-1996.-271, N 25.-P. 14876-14882.

78. Yang L. J., Zeller C. B., Shaper N. L., Kiso M., Hasegawa A., Shapiro R. E., Schnaar R. L. Gangliosides are neuronal ligands for myelin-associated glycoprotein // Proc. Nat. Acad. Sci. USA.-1996.-93, N 2.-P. 814-818.

79. Schnaar R. L. Brain gangliosides in axon-myelin stability and axon regeneration // FEBS Lett.-2009, Oct. 12 [Epub. ahead of print].

80. Takamiya K., Yamamoto A., Furukawa K., Yamashiro S., Shin M., Okada M., Fukumoto S., Haraguchi M., Takeda N., Fujimura K., Sakae M., Kishikawa M., Shiku H., Furukawa $K$., Aizawa $S$. Mice with disrupted GM2/GD2 synthase gene lack complex gangliosides but exhibit only subtle defects in their nervous system // Proc. Nat. Acad. Sci. USA.-1996.93, N 20.-P. 10662-10667.

81. Sheikh K. A., Sun J., Liu Y., Kawai H., Crawford T. O., Proia R. L., Griffin J. W., Schnaar R. L. Mice lacking complex gangliosides develop Wallerian degeneration and myelination defects // Proc. Natl. Acad. Sci. USA.-1999.-96, N 13.P. 7532-7537.

82. Sun J., Shaper N. L., Itonori S., Heffer-Lauc M., Sheikh K. A., Schnaar R. L. Myelin-associated glycoprotein (Siglec-4) expression is progressively and selectively decreased in the brains of mice lacking complex gangliosides // Glycobiology.-2004.-14, N 9.-P. 851-857.
83. Yamashita T., Wada R., Sasaki T., Deng C., Bierfreund U., Sandhoff K., Proia R. L. A vital role for glycosphingolipid synthesis during development and differentiation // Proc. Nat. Acad. Sci. USA.-1999.-96, N 16.-P. 9142-9147.

84. Yamashita T., Allende M. L., Kalkofen D. N., Werth N., Sandhoff K., Proia R. L. Conditional LoxP-flanked glucosylceramide synthase allele controlling glycosphingolipid synthesis // Genesis.-2005.-43, N 4.-P. 175-180.

85. Jennemann R., Sandhoff R., Wang S., Kiss E., Gretz N., Zuliani C., Martin-Villalba A., Jager R., Schorle H., Kenzelmann M., Bonrouhi M., Wiegandt H., Grone H. J. Cell-specific deletion of glucosylceramide synthase in brain leads to severe neural defects after birth // Proc. Nat. Acad. Sci. USA.2005.-102, N 35.-P. 12459-12464.

86. Kawai H., Allende M. L., Wada R., Kono M., Sango K., Deng C., Miyakawa T., Crawley J. N., Werth N., Bierfreund U., Sandhoff K., Proia R. L. Mice expressing only monosialoganglioside GM3 exhibit lethal audiogenic seizures // J. Biol. Chem.-2001.- 276, N 10.-P. 6885-6888.

87. Prinetti A., Loberto N., Chigorno V., Sonnino S. Glycosphingolipid behaviour in complex membranes // Biochim. Biophys. Acta.-2009.-1788, N 1.-P. 184-193.

88. Allende M. L., Proia R. L. Lubricating cell signaling pathways with gangliosides // Curr. Opin. Struct. Biol.-2002.12, N 5.-P. 587-592.

UDC 577.114.5:57.017.2 Received 10.01.10 